\title{
American Political Science Review
}

\section{Volume 17 1923}

Reprinted with the permission of the original publisher by Periodicals Service Company Germantown, NY 
Printed on acid-free paper.

This reprint was reproduced from the best original edition copy available.

NOTE TO THE REPRINT EDITION:

In some cases full page advertisements which do not add to the scholarly value of this volume have been omitted.

As a result, some reprinted volumes may have irregular pagination. 


\section{The American}

\section{Political Science Review}

BOARD OF EDITORS

EdWard S. Corwin,

Princeton University

Robert E. Cushman,

University of Minnesota

Walter F. Dodd,

Chicago, Illinois

Charles G. Fenwick,

Bryn Mawr College
W. B. MONRO,

Harvard University

Frederic A. Oga,

University of Wisconsin

Thomas H. Reed,

University of Michigan

W. W. WILLOUGHBY, Johns Hopkins University

John A. Fairite, Managing Editor,

Cuarence A. Berdahl, Acting Editor, University of Illinois

\section{VOLUME XVII}

1923

\section{BALTIMORE, MARYLAND}

THE WAVERLY PRESS 
Copyright, 1923 , by

THE AMERICAN POLITICAL BCIENCR ASSOCIATION 


\section{CONTENTS}

NUMBER 1-FEBrUARY, 1923

Liberty and Equality in International Relations, William A. Dunning ...... 1

State Morality in International Relations, Bruce Williams............ 17

Pluralism: A Point of View, George H. Sabine................... 34

The Influence of Political Platforms on Legislation in Indiana, Burton $Y$.

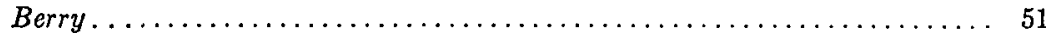

Legislative Notes and Reviews, Walter $F$. Dodd ................. 70

Illinois Rejects New Constitution; Constitutional Amendments in Ver-

mont, Edmund C. Mower; Indexing Statute Law, Gertrude E. Woodward;

Budgetary Legislation in 1922, Ruth Montgomery; Bonus Legislation in

Maryland, Niels H. Debel; The Presidential Ballot, L. E. Aylesworth.

News and Notes, Personal and Miscellaneous, Frederic A. Ogg . . . ...... 97

Activities of the Colorado Electorate, $R$. C. Spencer

Annual Meeting

Book Reviews, W. B. Munro.

Recent Publications of Political Interest:

Books and Periodicals, Clarence A. Berdahl. ............... 151

Government Publications, Rollin A. Sawyer, Jr.............. 177

NUMBER 2-MAT, 1923

Political Science as Psychology, Horace M. Kallen..................... 181

The Nature of Political Thought, Raymond $G$. Gettell. .............. 204

Democracy in Administration, Jennie McMullin Turner.............. 216

Legislative Notes and Reviews, Walter F. Dodd . . . . . . . . . . . . . . 231

Governors' Messages, Ralph S. Boots; The New York State Literacy Test,

F. D. Crawford: No Cabinet Government in Oregon, James D. Barnett

News and Notes, Personal and Miscellaneous, Frederic A. Ogg . . . . . . 265

Report of the Committee on Political Research................ 274

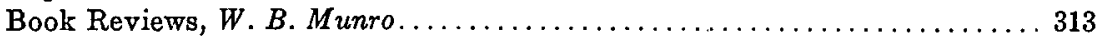

Recent Publications of Political Interest:

Books and Periodicals, Clarence A. Berdahl. . . . . . . . . . . . . . 354

Government Publications, Rollin A. Sawyer, Jr................

NUMBer 3-AUgust, 1923

Political Science in the International Field, Pitman B. Potter............ 381

International Politics and History, Henry R. Spencer . . . . . . . . . . . . . . 392

The Problem of Soverejgnty, Baron S. A. Korff . ................... 404

iii 
Notes on Municipal Affairs, Thomas $H$. Reed................. 415 Municipal Street Railway Operation in Detroit, C. E. Rightor; Public Utilities in other Cities, City Manager Plan, Report of the New York Charter Commission, Other Charter Revisions, Proportional Representation, Home Rule, Recall, Municipal Finance; Per Capita Taxation in Michigan Cities, Josephine Hoyt; City Planning, City-County Consolidation

Judicial Decisions on Public Law, Robert E. Cushman................ 434

Foreign Governments and Politics, Pitman B. Potter................. 445

Swiss Initiative Vote of December 3, 1922, Robert C. Brooks; The Constitution of Latvia, James $K$. Pollock, $J r$., American Influence on Political Thought in Czechoslovakia, Vaclav Parti.

News and Notes, Personal and Miscellaneous, Pitman B. Potter . . . . . . 483

The Teaching of International Law, Edwin D. Dickinson..........464

Book Reviews, A. C. Hanford. ....................... 477

Recent Publications of Political Interest:

Books and Periodicals, Clarence A. Berdahl.................523

Government Publications, Miles 0 . Price ................. 546

NUMBER 4-NOVEMBER, 1923

The Political System of Imperial China, Harold S. Quigley........... 551

Growth of Presidential Government in Europe, Charles E. Martin........ $56^{7}$

Guild Socialism and Pluralism, Ellen D. Ellis . . . . . . . . . . . . . 584

Legislative notes and Reviews, Walter $F$. Dodd ............... 597

Fiscal and Administrative Reorganization in Pennsylvania, Clyde L. King;

Judicial Council in Ohio, Clarence D. Laylin; Judicial Council in Oregon,

James D. Barnett.

Foreign Governments and Politics, Frederic $A . O g g \ldots \ldots \ldots \ldots \ldots \ldots \ldots 612$

International Status of the British Dominions, C. D. Allin; Recent

Articles in Foreign Periodicals, L. D. White, Raymond L. Buell, Harold C. Harrighurst.

News and Notes, Personal and Miscellaneous, Frederic A. Ogg . . . . . 635

Book Reviews, A. C. Hanford. . ........................ 650

Recent Publications of Political Interest:

Books and Periodicals, Clarence A. Berdahl . . . . . . . . . . . . . 697

Government Publications, Miles O. Price . . . . . . . . . . . . . . . . . . 719

Index to Volume XVII . . . . . . . . . . . . . . . . . . . . . . . 727 